\title{
Effect of Vermicompost on Yield and Yield Components of Two Corn Cultivars
}

\author{
Saeed Samsami
}

Jobholder of Agriculture, Bank Management of Fars province

\begin{abstract}
This study was performed for evaluation of vermicompost Effect on yield and yield components of two corn cultivars. First factor included cultivars (S.C 704, B.C 666) and second factor included vermicompost treatments (control, 25, 50, 75 and 100\%), also some properties were studied such as highest plant height, number of seeds,1000seed weight, seed yield, biological yield, harvest index\%.Totally, according to result, S.C 704 had best results and it treatment showed highest plant height (221.6 $\mathrm{cm})$, number of seeds (773.4),1000-seed weight (150.46 g), seed yield $\left(9.7 \mathrm{tha}^{-1}\right)$, biological yield $(19412 \mathrm{~kg} / \mathrm{h})$, harvest index\% (50.36\%). Between vermicomposttreatment, application of $75 \%$ led to 61, 43, 73, 65, 80 and 80 percentage of highest plant height, number of seeds, 1000seed weight, seed yield, biological yield, harvest index\% in compare to control.
\end{abstract}

Keywords-Conr, Cultivars, Vermicompost.

\section{INTRODUCTION}

Fertilizers are the major sources of nutrients for crops, also organic matter in soil influences almost all the components of soil linked with crop production (Bhatt et al., 2012). The compost prepared through the application of earthworms is called vermicompost and the technology of using local species of earthworms for culture or composting has been called Vermitech (Ismail, 2005). The role of vermicompost as organic manure in improving soil fertility and productivity is well documented. In addition to its richness in essential plant nutrients, it also supplies plant growth promoting substances, humus forming microbes and $\mathrm{N}$ fixers in the soil (Lenin et al., 2010). Organic manures act not only as a source of nutrients and organic matter, but also increase size, biodiversity and activity of the microbial population in soil, influence structure, nutrients get turnover and many other change related to physical, chemical and biological parameters of the soil (Albiach et al., 2000).Vermicomposting is one such viable technique for augmentation of organic source in soil, also, Application of vermicompost influences the physical, chemical and biological properties of soil, It improves the water holding capacity of the soil and it possesses vitamins and growth hormones which have a direct role on plant growth. Integrated use of organic $\mathrm{N}$ through vermicompost and fertilizer $\mathrm{N}$ enhanced the growth and yield attributes of crops (Thirunavukkarasu and Vinoth, 2013). Among the sources of available organic manures vermicompost is a potential source due to the presence of readily available plant nutrients, growth enhancing substances, and a number of beneficial microorganisms like nitrogen fixing, $\mathrm{P}$ solubilising and cellulose decomposing organisms (Kumari and Ushakumari., 2002). Also, it was mentioned that vermicompost substrates had significant effect on amount of organic elements, so yield of crops affect by vermicompost substrates, Malekiet al (2016) evaluated vermicompost substrates Effect on amount of organic carbon, total Nitrogen and Carbon to Nitrogen ratio and they reported that best treatment is manure + leave in compare to control and manure + sawdust and paper. Corn is an important cereal crop that provides staple food to large number of human population in the world. It is a tropical plant but at present its cultivation in subtropical and temperate regions is also done intensively on worldwide bases and it can successfully be cultivated twice in a year. In developing countries maize is a major source of income to many farmers (Tagneet al., 2008).In environments with low nutrient concentrations or the new reclaimed lands, plants are stressed directly by the lack of adequate nutrients (Emanet al., (2007) Farming practices, which involve heavy application of chemical fertilizers, may cause depletion of certain nutrients in soil and certain others would generally accumulate in excess resulting in nutrient imbalance, which affects soil productivity. Among available means to achieve sustainability in agricultural production, organic manure and bio-fertilizer play an important and key role because they possesses many desirable soil properties and exerts beneficial effect on soil physical, chemical and biological characteristics (Son et al., 2004). Organic materials are used for increasing crop production but pure organic farming can 
never meet the increasing demand for nutrient supply, as sufficient quantities of organic materials are not available. So, the aim of this study wasevaluation of vermicompost Effect on yield and yield components of two corn cultivars.

\section{MATERIAL AND METHODS}

This study was performed as factorial in CRD design, First factor included cultivars (S.C 704, B.C 666) and second factor included vermicompost treatments (control, 25, 50, 75 and $100 \%$ ), also some properties were studied such ashighest plant height, number of seeds,1000-seed weight, seed yield, biological yield, harvest index $\%$.

\section{RESULT AND DISCUSSION}

Plant height:According to results, it was founded that there was significant differences between cultivars and highest plant height $(221.6 \mathrm{~cm})$ was obtained by S.C 704 . Application of 25, 50, 75 and $100 \%$ of vermicompost led to $21,42,61$ and $54 \%$ increasing of plant height in compare to control. Also, interaction between cultivars and vermicompost, it was founded that S.C 704 with $75 \%$ vermicompost showed highest means $(258 \mathrm{~cm})$.

Number of Seeds: According to results, it was founded that there was significant differences between cultivars and highest number of seeds (773.4) was obtained by S.C 704. Application of $25,50,75$ and $100 \%$ of vermicompost led to 9, 19, 43 and $33 \%$ increasing of number of seeds in compare to control. Also, interaction between cultivars and vermicompost, it was founded that S.C 704 with $75 \%$ vermicompost showed highest means (898).

1000-seeds weight: According to results, it was founded that there was significant differences between cultivars and highest 1000 -seeds weight (150.46 g) was obtained by S.C 704. Application of 25, 50, 75 and $100 \%$ of vermicompost led to $3,19,73$ and $38 \%$ increasing of 1000-seeds weight in compare to control. Also, interaction between cultivars and vermicompost, it was founded that S.C 704 with $75 \%$ vermicompost showed highest means $(219.1 \mathrm{~g})$.

Seed yield: According to results, it was founded that there was significant differences between cultivars and highest seed yield $\left(9.7 \mathrm{tha}^{-1}\right)$ was obtained by S.C 704. Application of $25,50,75$ and $100 \%$ of vermicompost led to $4,22,65$ and $59 \%$ increasing of seed yield in compare to control. Also, interaction between cultivars and vermicompost, it was founded that S.C 704 with $75 \%$ vermicompost showed highest means (12.6t ha-1).

Biological Yield: According to results, it was founded that there was significant differences between cultivars and highest biological yield $(19412 \mathrm{~kg} / \mathrm{h}$ ) was obtained by S.C 704. Application of 25, 50, 75 and $100 \%$ of vermicompost led to $13,35,80$ and $65 \%$ increasing of biological yield in compare to control. Also, interaction between cultivars and vermicompost, it was founded that S.C 704 with $75 \%$ vermicompost showed highest means $(24922 \mathrm{~kg} / \mathrm{h})$.

harvest index \%: According to results, it was founded that there was significant differences between cultivars and highest harvest index\% (50.36\%) was obtained by S.C 704. Application of 25, 50, 75 and $100 \%$ of vermicompost led to $1.13,1.35,1.80$ and 1.65 fold increasing of harvest index\% in compare to control. Also, interaction between cultivars and vermicompost, it was founded that B.C 666 with novermicompost showed highest means $(53.45 \%)$.Organic amendments like vermicompost promote humification, increased microbial activity and enzyme production, which, in turn, bring about the aggregate stability of soil particles, resulting in better aeration (Perucci, 1990). Organic matter has a property of binding mineral particles like calcium, magnesium and potassium in the form of colloids of humus and clay, facilitating stable aggregates of soil particles for desired porosity to sustain plant growth. Soil microbial biomass and enzyme activity are important indicators of soil improvement as a result of addition of organic matter (Ansari, 2008). The results of several long-term studies have shown that the addition of compost improves soil physical properties by decreasing bulk density and increasing the soil water holding capacity (Weber, 2007). Moreover, in comparison with mineral fertilizers, compost produces significantly greater increases in soil organic carbon and some plant nutrients (Nardi, 2004).Totally, according to result, S.C 704 had best results and it treatment showed highest plant height $(221.6 \mathrm{~cm})$, number of seeds (773.4),1000-seed weight (150.46 g), seed yield $\left(9.7 \mathrm{t} \mathrm{ha}^{-1}\right)$, biological yield $(19412 \mathrm{~kg} / \mathrm{h})$, harvest index\% (50.36\%). Between vermicomposttreatments, application of $75 \%$ led to 61,43 , $73,65,80$ and 80 percentage of highest plant height, number of seeds, 1000-seed weight, seed yield, biological yield, harvest index\% in compare to control.

Table.1: Means comparison of studied traits in responses to treatments

\begin{tabular}{|c|c|c|c|c|c|c|}
\hline Treatments & $\begin{array}{l}\text { Plant height } \\
(\mathrm{cm})\end{array}$ & $\begin{array}{l}\text { Number. of } \\
\text { seeds cob-1 }\end{array}$ & $\begin{array}{l}1000 \text {-seed } \\
\text { weight }(\mathrm{g})\end{array}$ & $\begin{array}{l}\text { Seed yield (t } \\
\text { ha-1) }\end{array}$ & $\begin{array}{c}\text { Biological } \\
\text { Yield (kg/h) }\end{array}$ & $\begin{array}{l}\text { harvest } \\
\text { index } \%\end{array}$ \\
\hline control & 161 & 646.3 & 120.8 & 7.268 & 13652 & 53.24 \\
\hline 25 & 203 & 691.3 & 123.8 & 7.812 & 16722 & 46.72 \\
\hline
\end{tabular}




\begin{tabular}{|c|c|c|c|c|c|c|c|c|c|c|c|c|c|}
\hline \multirow[t]{3}{*}{ S.C 706} & 50 & 228 & c & 784 & $\mathrm{c}$ & 124.1 & $\mathrm{f}$ & 8.771 & $\mathrm{~cd}$ & 17872 & de & 49.08 & d \\
\hline & 75 & 258 & $\mathrm{a}$ & 898.3 & $\mathrm{a}$ & 219.1 & $\mathrm{a}$ & 12.67 & $\mathrm{a}$ & 24922 & $\mathrm{a}$ & 50.84 & $\mathrm{c}$ \\
\hline & 100 & 258 & $\mathrm{a}$ & 847 & b & 164.5 & $\mathrm{c}$ & 12.41 & a & 23892 & b & 51.94 & bc \\
\hline \multirow{5}{*}{ B.C 666} & control & 154 & $\mathrm{~g}$ & 581.3 & d & 114.5 & $\mathrm{f}$ & 6.49 & $\mathrm{f}$ & 12142 & $\mathrm{f}$ & 53.45 & $\mathrm{a}$ \\
\hline & 25 & 178 & $\mathrm{f}$ & 642 & $\mathrm{e}$ & 119.1 & $\mathrm{f}$ & 6.51 & $\mathrm{f}$ & 12442 & f & 52.32 & $a b$ \\
\hline & 50 & 218 & d & 678.6 & d & 155.8 & $\mathrm{c}$ & 8.052 & de & 16932 & e & 47.55 & e \\
\hline & 75 & 248 & b & 855.3 & b & 187.1 & b & 10.093 & $\mathrm{~b}$ & 21522 & $\mathrm{c}$ & 46.90 & $\mathrm{e}$ \\
\hline & 100 & 228 & c & 789.3 & c & 160.8 & $\mathrm{c}$ & 9.494 & bc & 18712 & d & 50.74 & $\mathrm{c}$ \\
\hline
\end{tabular}

\section{REFERENCES}

[1] Albiach, R., R. Canet, F. Pomares and F. Ingelmo. 2000. Microbial biomass content and enzymatic activities after the application of organic amendments to a horticultural soil. Bioresour. Technol., 75: 43-48.

[2] Ansari, A. 2008. Effect of Vermicompost and Vermiwash on the Productivity of Spinach (Spinaciaoleracea), Onion (Allium cepa) and Potato (Solanumtuberosum). World Journal of Agricultural Sciences 4 (5): 554-557,

[3] Bhatt, B., R. Chandra and S. Ram. 2012. Long-term application of fertilizer and manure on rice productivity and soil biological properties. International Journal of Agriculture, Environment and Biotechnology 5(4): 429433.

[4] Eman. M. F., Saidy. E. (2007) Effect of Seed rates, Nitrogen fertilizer and Bio fertilizers on panicumantidotale under Ras surd conditions Egypt. J. Agron. Vol 29, No. 143 - 67.

[5] Ismail, S.A. 2005. The Earthworm Book. Other India Press, apusa, Goa, pp: 101.

[6] Kumari, M.S. and Ushakumari, K., 2002. Effect of vermicompost enriched with rock phosphate on the yield and uptake of nutrients in cowpea (Vignaunguiculata L. Walp). J. Trop. Agric, 40, pp.27-30.

[7] Lenin M, Selvakumar G, Thamizhiniyan P, Rajendiran R .2010. Growth and biochemical changes of vegetable seedlings induced by arbuscularmycorrhizal fungus. J. Exp. Sci., 1: 27-31.

[8] Nardi S, Morari F, Berti A, Tosoni M and Giardini L. 2004. Soil organic matter properties after 40 years of different use of organic and mineral fertilisers. European Journal of Agronomy 21, 357-367.

[9] Perucci, P. (1990). Effect of the addition of municipal solid-waste compost on microbial biomass and enzyme activities in soil. Biol. Fertil. Soils., 10: 221.

[10] Son Tran Thi Ngoc, Thu Vu van, Man Luu Hong, Kobayashi H, and Yamada R . (2004). Effect of long- term application of organic and biofertilizer on soil fertility under Rice- Soybean-Rice cropping system.Omonrice 12: 45-51

[11] Tagne, A., Feujio. T.P. and C. Sonna. (2008). Essential oil and plant extracts as potential substitutes to synthetic fungicides in the control of fungi. International Conference Diversifying crop protection, 12-15 October La Grande-Motte, France

[12] Thirunavukkarasu, M and R, Vinoth, 2013. Influence of Vermicompost application alongwith Nitrogen on Growth, Nutrients uptake, Yield Attributes and Economics of Rice (Oryza sativa L.). International Journal of Agriculture, Environment \& Biotechnology, 6(4): 599-604

[13] Weber J, Karczewska A, Drozd J, Licznar M, Licznar S, Jamroz E and Kocowicz A. 2007. Agricultural and ecological aspects of a sandy soil as affected by the application of municipal solid waste composts. Soil Biology and Biochemistry, 39, 1294-1302. 